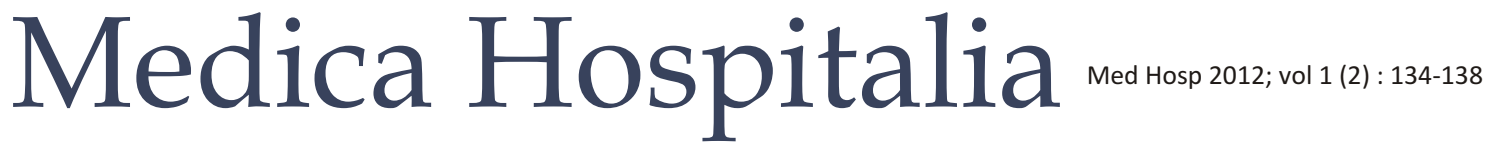

Case Report

\section{Percutaneous Balloon Mitral Valvuloplasty pada Wanita Hamil 22 Minggu akibat Mitral Stenosis Berat dengan Penyulit Gagal Jantung Kongestif dan Hipertensi Pulmonal berat}

\author{
Charles Limantoro*, Sodiqur Rifqi ${ }^{* *}$, Adityana ***, Intan Surayya*** \\ *Divisi Kardiologi, Departemen Penyakit Dalam FK UNDIP/RSUP Dr. Kariadi Semarang, **Departemen Kardiologi FK UNDIP/ \\ RSUP Dr. Kariadi Semarang, ${ }^{* * *}$ Peserta PPDS-1 Departemen Penyakit Dalam FK UNDIP/RSUP Dr. Kariadi Semarang
}

\begin{abstract}
Abstrak
Latar Belakang : Gagal jantung kongestif (GJK) pada wanita hamil merupakan masalah kritis karena tingkat kesakitan dan kematian ibu dan janin yang tinggi. Salah satu penyebab utama GJK adalah stenosis mitral (SM) yang merupakan lesi katup pada penyakit jantung rematik (PJR) yang paling sering dijumpai. Perubahanperubahan kardiovaskular yang terjadi pada saat kehamilan seringkali memunculkan berbagai gejala dan tanda gangguan katup mitral pada PJR.

Kasus : Seorang wanita 36 tahun, hamil 22 minggu, kehamilan ke-6, dengan keluhan utama sesak napas, dirujuk ke RSUP Dr. Kariadi. Pasien didiagnosis sebagai gagal jantung kongestif (GJK) NYHA IV, dengan hipertensi pulmonal (HP) berat, stenosis mitral (SM) sedang-berat et causa PJR. Dilakukan Percutaneous Balloon Mitral Valvuloplasty (PBMV) untuk meringankan gejala gagal jantung dan mengurangi derajat HP dan Trans Esophageal Echocardiography (TEE) untuk memastikan ada atau tidak adanya thrombus di LAA dan mitral regurgitasi. Hasil TEE didapatkan PJR dengan SM sedang-berat, trikuspid regurgitasi sedang-berat, aortic regurgitasi ringan dan HP berat.

Diskusi : Perkembangan baru dalam penanganan penyakit katup meliputi Percutaneous Balloon Mitral Valvuloplasty (PBMV) untuk stenosis mitral. Penggunaannya pada pasien hamil harus diperhitungkan dengan matang, untuk memastikan kelangsungan hidup ibu dan meningkatkan kesejahteraan janin. Untuk penatalaksanaan mitral stenosis pada kehamilan dibutuhkan informasi mengenai derajat dan beratnya penyakit serta komplikasi yang terjadi pada penderita.

Simpulan : Percutaneous Balloon Mitral Valvuloplasty dapat dilakukan pada wanita hamil dengan GJK dan hipertensi pulmonal dengan mempertimbangkan derajat penyakit, komplikasi dan penyulit lainnya.
\end{abstract}

\author{
Percutaneous Balloon Mitral Valvuloplasty \\ Treatment Conducted at $22^{\text {nd }}$ Weeks \\ Pregnancy Woman With Congestive Heart Failure \\ and Pulmonary Hypertension
}

Abstract

Background : Congestive Heart Failure (CHF) in pregnancy is a critical condition due to its high maternal and fetal mortality. One of the leading cause of $\mathrm{CHF}$ is mitral stenosis related with rheumatic heart disease. Normally this condition requires pregnancy termination, however percutaneous balloon mitral valvuloplasty (PBMV) showed is the most frequently encountered rheumatic valve lesion. A variety of pregnancy-associated cardiovascular changes often exacerbate the signs and symptoms of valve lesions.

Case : A 36 year, $22^{\text {nd }}$ week pregnancy woman with dyspnea referred to Dr. Kariadi hospital. She was diagnosed congestive heart failure (CHF) based on New York Heart Association (NYHA) IV class, with severe pulmonary hypertension $(\mathrm{PH})$ and moderate to severe mitral stenosis (MS) et causa rheumatic heart disease (RHD). Termination of pregnancy was recommended to save the mother, but the patient refused. To relieve CHF symptoms and reduce the degree of $\mathrm{PH}, \mathrm{PBMV}$ was done. Meanwhile Trans Esophageal Echocardiography (TEE) was conducted to examine thrombus and mitral regurgitation, and it revealed suggested rheumatic heart disease moderate-severe mitral stenosis dan tricuspid regurgitation, mild aortic regurgitation, and severe pulmonary hypertension.

Discussion : New technique development in the mitral valve disease is percutaneous balloon mitral valvuloplasty for mitral stenosis. To use PBMV in pregnant patients should be considered due to the safety of the mother and fetus. The comorbidity such as the severity of mitral stenosis, status of thrombus, heart failure and pulomanary hypertension sould be considered, weighing the risks and benefits in each individual, to ensure the survival of the mother and improve the welfare of the fetus. Taking PBMV as the option of treatment, the condition of patient including severity and complication had to be considered carefully.

Conclusion : PBMV treatment on pregnant woman suffering from $\mathrm{CHF}$ and pulmonary hypertension can be done after considering the severity of the disease and complication. 


\section{LAPORAN KASUS}

Seorang wanita umur 36 tahun hamil 22 minggu, anak ke-6, dirujuk dari Puskesmas Karang Tengah Demak dengan keluhan sesak nafas. Sudah sejak 4 tahun ini (saat awal kehamilan anak ke 5), pasien mulai merasakan sesak napas yang memberat dengan aktivitas sedang. Pasien tidak berobat teratur di RSUD Demak. Dalam 1 bulan terakhir, sesak semakin berat, duduk diam sekalipun pasien tetap merasa sesak napas. Pasien tidak demam, tidak nyeri dada. Kedua kaki bengkak dalam 2 minggu terakhir. Selama ini pasien memeriksakan kehamilan pada dukun bayi setempat, gerak janin masih dirasakan.

Riwayat sakit jantung telah diketahui sejak \pm 4 tahun yang lalu saat mulai hamil anak ke-5. Tidak ada riwayat operasi (tonsilektomi). Tidak ada riwayat gerakan-gerakan yang tidak dapat dikendalikan maupun nyeri sendi yang berpindah disertai bengkak sendi. Pasien tidak punya riwayat asma, darah tinggi maupun kencing manis. Kelima anak sebelumnya lahir spontan, cukup bulan, persalinan ditolong dukun bayi. Anak keempat meninggal saat usia 55 hari karena demam.
Pada pemeriksaan fisik dijumpai pasien kompos mentis, posisi setengah duduk, orthopneu, terpasang oksigen kanul nasal $3 \mathrm{l} / \mathrm{m}$. Tekanan darah $120 / 70 \mathrm{mmHg}$, frekuensi jantung 120x/menit, regular, frekuensi napas $28 \mathrm{x} /$ menit, suhu $37^{\circ} \mathrm{C}$. Pemeriksaan kulit tidak ada sianosis, tidak ada lesi Janeway, tidak ada nodus Osler, tidak ada eritema marginatum maupun nodul subkutan. Tidak terlihat adanya fasies mitral, tidak ada konjungtiva palpebra yang pucat atau sklera ikterik. Pada leher terlihat distensi vena jugularis. Iktus kordis bergeser ke lateral, pinggang jantung cembung. Teraba thrill diastolik di apeks, teraba pulsasi parasternal, epigastrial dan didapatkan sternal lift. Bunyi Jantung (BJ) I mengeras, opening snap (+), P2 mengeras. Didapatkan bising diastolik kresendo, rumbling, bernada rendah, grade 4/6, punctum maksimum di apeks jantung, tidak dijalarkan. Juga terdapat bising diastolik lainnya, dekresendo, meniup, bernada tinggi, grade $2 / 6$, punctum maksimum di daerah spasium inter-costae (s.i.c) 2 kanan tepi tulang sternum menjalar sampai ke parasternal kiri bawah. Di daerah s.i.k 4-5 kiri dari tepi sternum terdengar bising sistolik, dekresendo, meniup, bernada tinggi, grade $3 / 6$, tidak dijalarkan, Carvallo,s

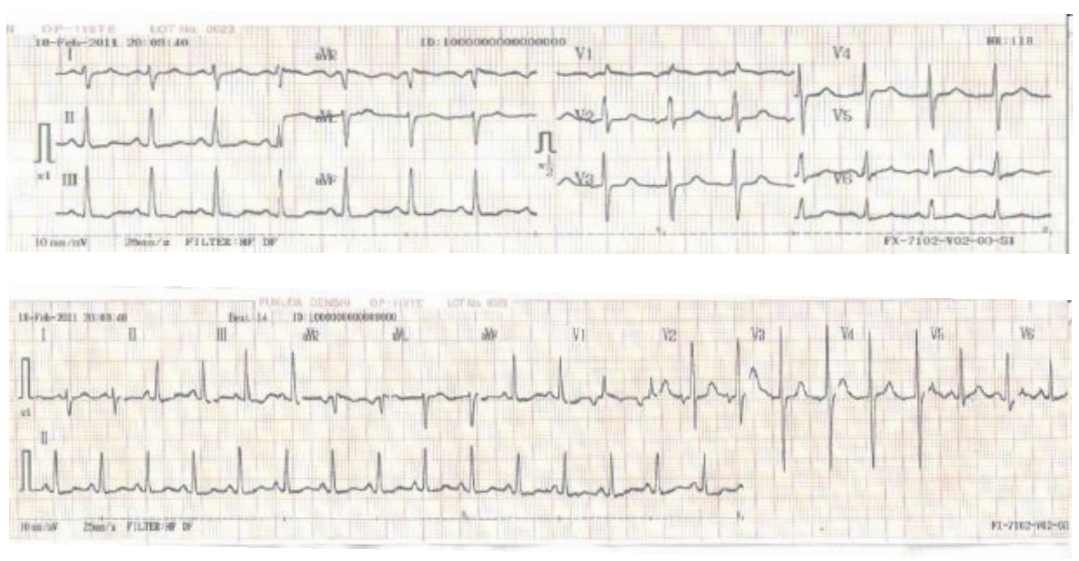

Gambar 1. EKG pasien (sinus takikardi, RVH, LAE)

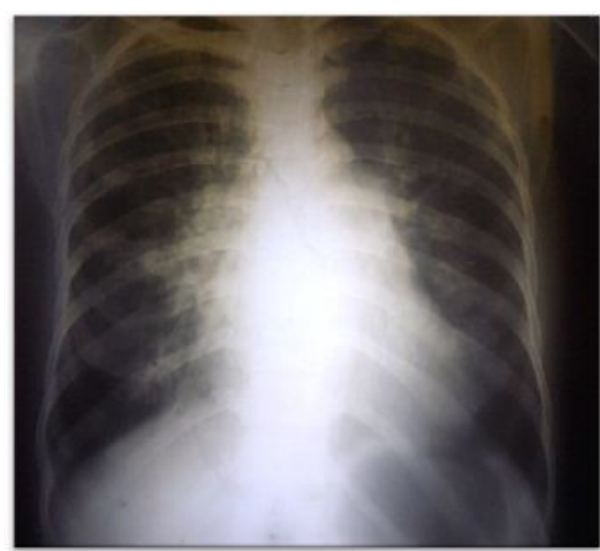

Gambar 2. Foto rontgen (RVH, LAE, penonjolan Conus Pulmonalis)

\section{TABELL 1}

\section{Kriteria Jones (Demam Reumatik Akut)}

Kriteria Mayor

Karditis $\rightarrow(-)$

Poliarthritis $\rightarrow(-)$

Syndenham Chorea $\rightarrow(-)$

Eritema Marginatum $\rightarrow(-)$

Nodul subkutan $\rightarrow(-)$

\section{Kriteria Minor}

\section{Arthralgia migran $\rightarrow(-)$}

Demam $\rightarrow(-)$

Peningkatan reaksi fase akut (LED, CRP, Leukositosis) $\rightarrow(+)$

EKG : pemanjangan interval PR $\rightarrow(-)$
Bukti Ada Infeksi Streptococcal
ASTO $\rightarrow(-)$

kultur swab tenggorok (+) untuk streptococci group $A \rightarrow(-)$ 

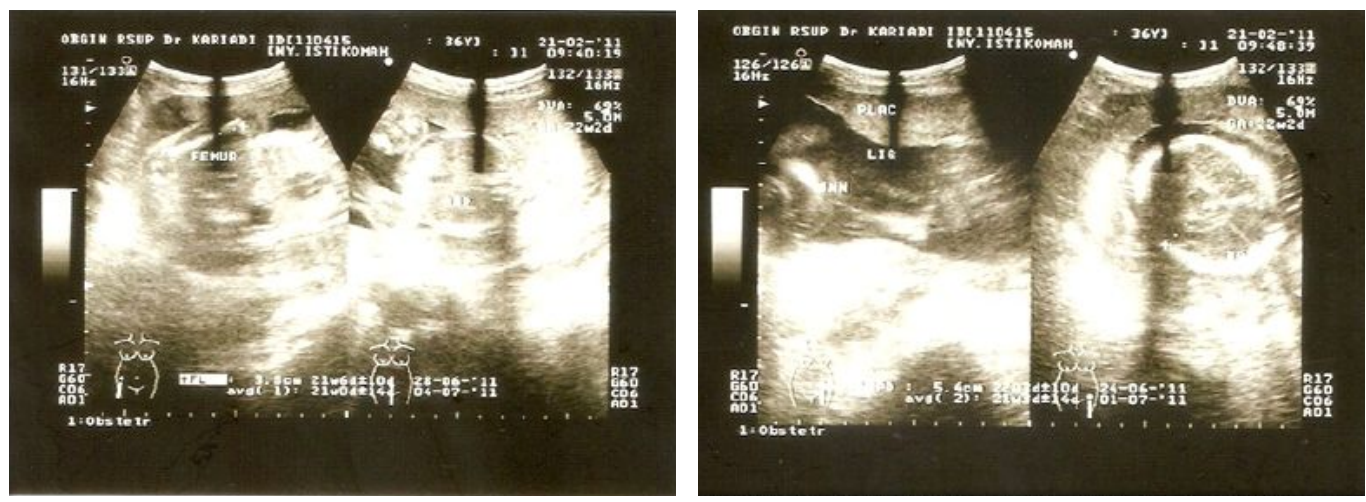

Gambar 3. USG obstetri
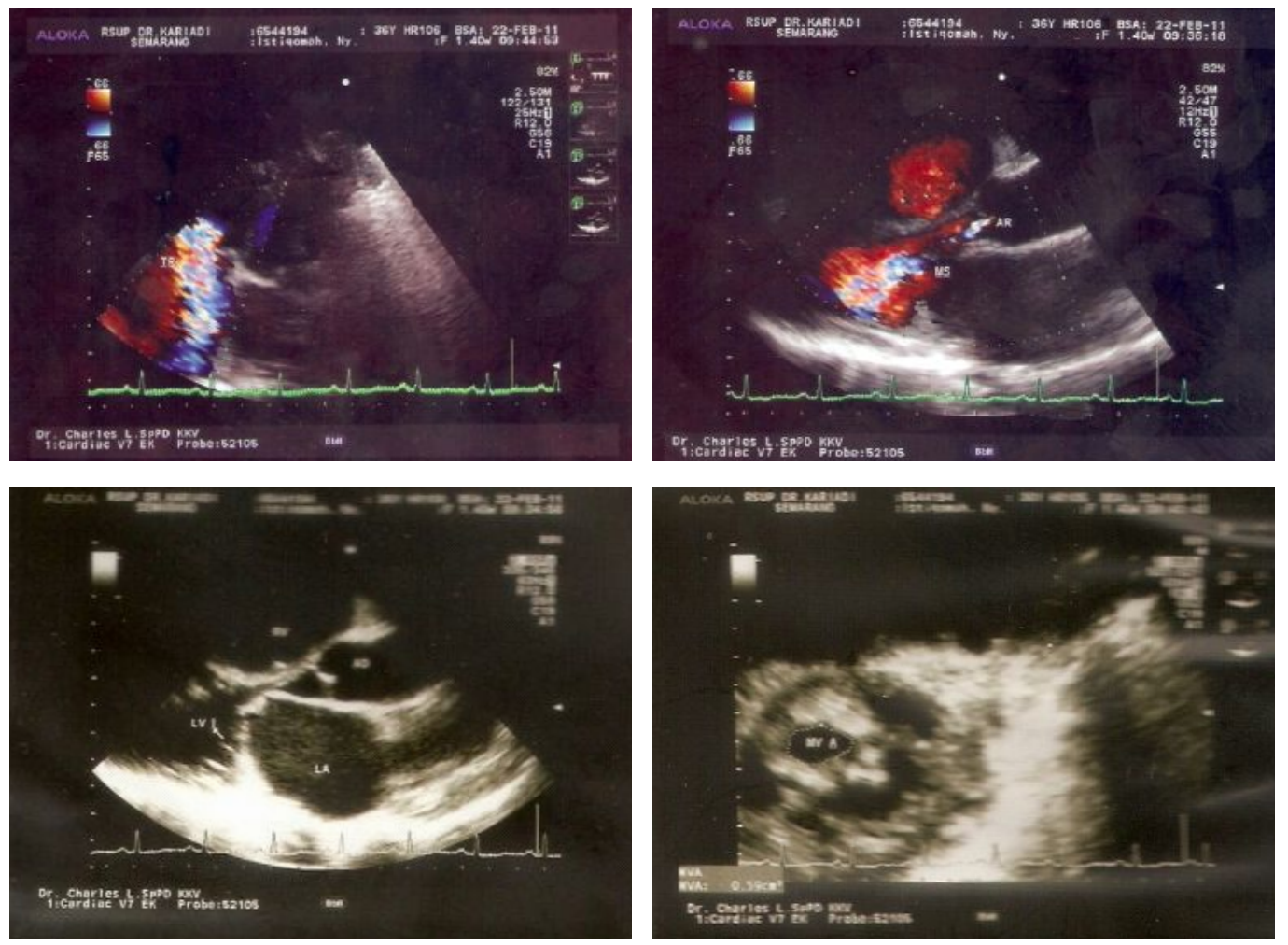

Gambar 4. Trans Thorakal Ekokardiografi

Sign (+). Tidak didapati adanya Gallop maupun Friction rub. Pada pemeriksaan fisik paru ditemukan adanya ronki basah halus pada separo lapangan paru kanan dan kiri, suara dasar vesikuler. Pada abdomen didapatkan hepatomegali $2 \mathrm{~cm}$ bawah arkus kosta, konsistensi kenyal, tepi tumpul, permukaan rata, tidak nyeri tekan. Tidak didapatkan sianosis dan jari tabuh, didapatkan edem pitting di kedua ekstremitas inferior.

Laboratorium menunjukkan Anemia hipokromik mikrositik (Hb 10,5 gr/dl) dengan LED I/II meningkat (48/78), Antistreptolysin O antibody (ASTO) negatif, C-Reactive Protein positif, dan kultur swab tenggorok streptococci group A (-). Tes laboratorium untuk fungsi ginjal tidak menunjukkan adanya kelainan yang berarti.
Fungsi hati sedikit terganggu. Tidak ada kelainan koagulasi yang berarti. Kriteria Jones pada tabel 1 tidak menunjukkan adanya demam rematik akut.

\section{DISKUSI}

Pasien wanita 36 tahun, hamil 22 minggu, kehamilan ke 6 dengan sesak nafas. Dari anamnesis dan pemeriksaan fisik ditetapkan GJK NYHA IV akibat penyakit jantung katup. Hasil pemeriksaan penunjang foto rontgen thoraks, EKG dan ekokardiografi menunjukkan diagnosis etiologi : PJR (SM sedang-berat) dengan Hipertensi Pulmonal berat. ${ }^{1}$ Tidak adanya klinis demam rematik akut (Kriteria Jones tidak terpenuhi). ${ }^{2}$ PJR sudah 

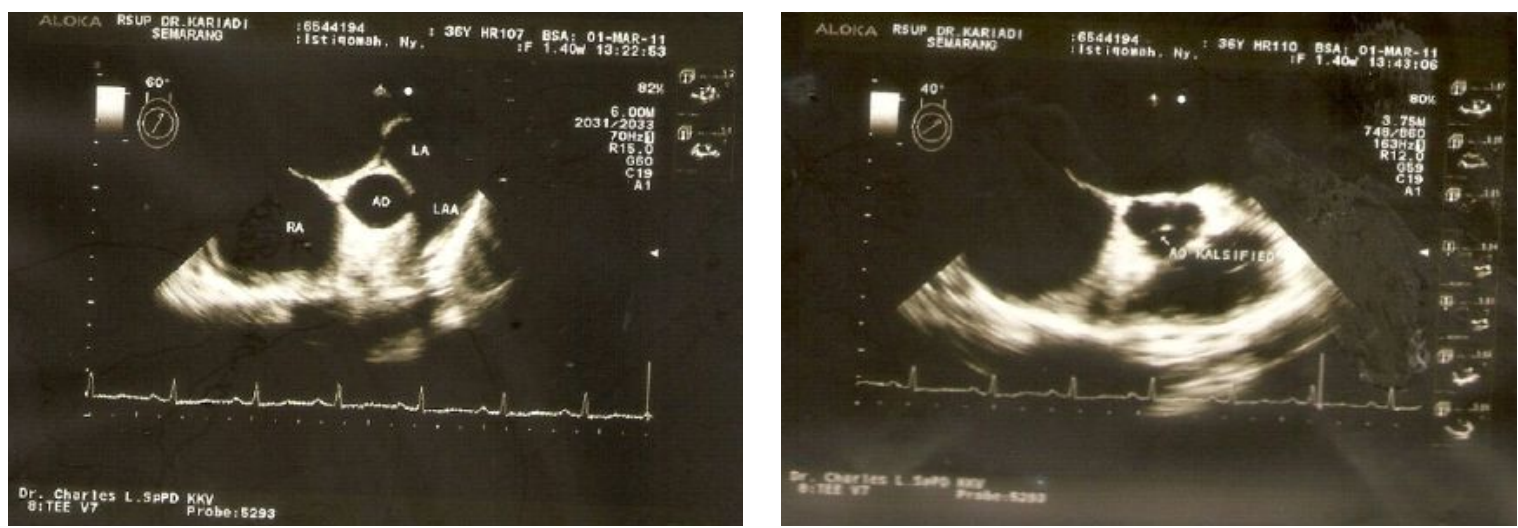

Gambar 5. Trans Esophageal Echocardiography
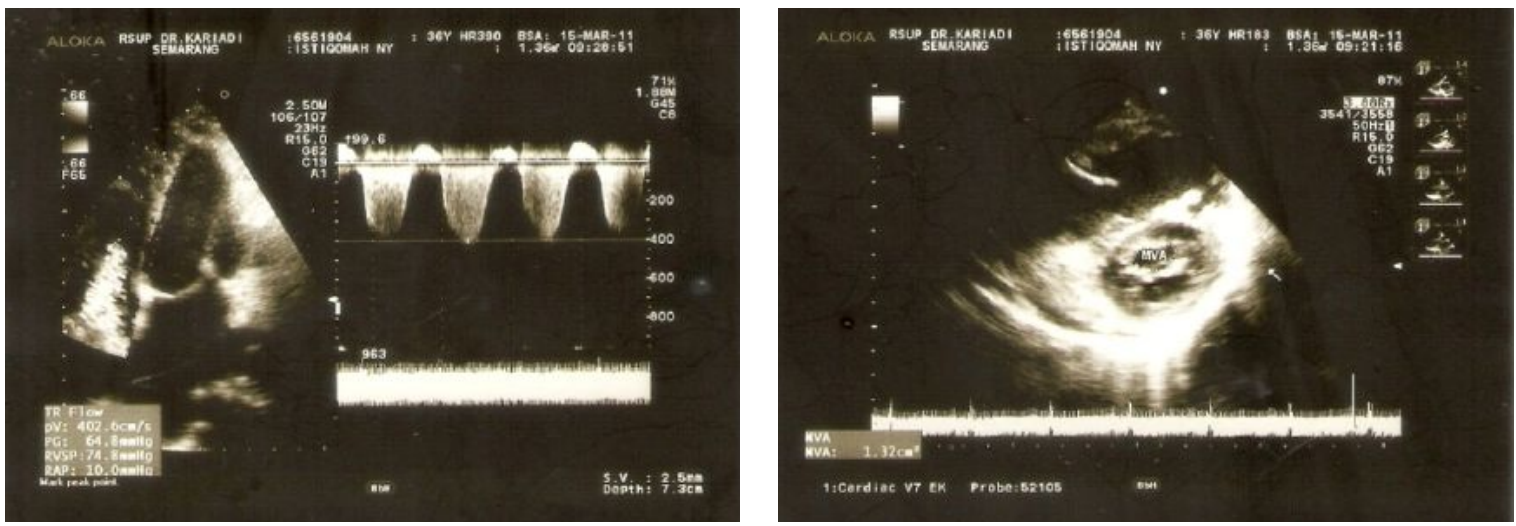

Gambar 6. TTE paska tindakan

lama terjadi,hal ini tampak dari pembesaran ruangruang jantung, fibrosis dan kalsifikasi berat katup mitral, dan hipertensi pulmonal. ${ }^{1,3}$ Pasien dengan kondisi seperti ini memiliki risiko tinggi untuk melanjutkan kehamilan. ${ }^{2,5,6}$ Dipertimbangkan terminasi kehamilan dengan pertimbangan keselamatan ibu dan janin, namun pasien menolak. Untuk meringankan GJ dan HP dipertimbangkan tindakan PBMV sehingga pasien dapat melanjutkan kehamilannya dengan lebih aman. ${ }^{5}$

Karena dari hasil TTE belum tergambar jelas ada tidaknya thrombus di LAA, perlu dilakukan pemeriksaan Trans Esophageal Echocardiography (TEE) seperti pada gambar 5, untuk memastikan keberadaan thrombus di LAA dan Mitral Regurgitasi. ${ }^{4-7}$

Hasil TEE tidak menunjukkan kontraindikasi dilakukan tindakan PBMV (tidak ada MR sedang-berat, tidak ada thrombus di LA/LAA, skor Wilkin 8). Tindakan dilakukan di ruang kateterisasi, dan pada bagian perut ibu hamil perlu dilindungi dengan apron anti radiasi. Sebelum dan setelah PBMV dilakukan pemeriksaan gradient katup mitral dengan penyadapan jantung kanan (kateterisasi) perkutan. TTE post PBMV juga kembali dikerjakan, idealnya setelah tindakan PBMV langsung dilakukan pemeriksaan TEE di ruang kateterisasi, namun sampai saat ini belum ada alat TEE yang tersedia di ruang kateterisasi. Hasil evaluasi TTE paska tindakan (gambar 6), didapatkan Mitral Stenosis tingkat sedang menjadi ringan, Mitral Regurgitasi tetap negatif, dan perbaikan Hipertensi Pulmonal dari tingkat berat menjadi sedang.

Secara klinis sesak membaik, CHF NYHA IV menjadi NYHA II. Kehamilan dapat dipertahankan sampai usia janin cukup matang. Pada kehamilan 31 minggu pasien datang ke RSDK dengan keluhan kenceng-kenceng, dilakukan evaluasi: inpartu kala I, partus prematur. Dikerjakan partus pervaginam dengan mempercepat kala II, pada pasien ini dilakukan episiotomi lebar, namun saat inpartu terjadi perdarahan banyak dari jalan lahir dan DJJ janin sudah tidak ada. Kematian janin saat lahir (still birth) dikarenakan adanya vasa previa dan insersio vilamentosa. Adakalanya tali pusat tidak berinsersi pada jaringan plasenta, tetapi pada selaput janin sehingga pembuluh darah umbilikus berjalan diantara amnion dan korion menuju plasenta. Kelainan ini disebut insersio vilamentosa dan jika pembuluh darah tersebut berjalan melalui pembukaan serviks disebut vasa previa. Kedua hal tersebut dapat terjadi pada pasien ini, di mana pembuluh darah robek 
saat ketuban pecah pada permulaan persalinan, sehingga terjadi perdarahan intrapartum dan keadaan janin menjadi buruk karena kehilangan darah atau asfiksi. ${ }^{8,9}$

\section{SIMPULAN}

Terminasi kehamilan pada penderita gagal jantung kronik dengan penyakit jantung rematik dan hipertensi pulmonal berat, bukan satu-satunya jalan. Berdasarkan hasil evaluasi dan pemeriksaan lanjut, bila lebih banyak keuntungan daripada kerugiannya, dan tidak ada indikasi kontra, maka dilakukan tindakan PBMV. Pada kasus ini tindakan PBMV dapat dilakukan pada penderita MS berat dengan penyulit GJK dan hipertensi pulmonal, pada kehamilan 22 minggu memberikan hasil yang baik sehingga pasien dapat mempertahankan kehamilannya hingga aterm. Tindakan PBMV dapat menjadi pilihan pada ibu hamil penderita gagal jantung karena MS Berat.

\section{DAFTAR PUSTAKA}

1. Miller C A, O'gara P T, Lilly L S. Valvular heart disease. In: Lilly L S (Ed) Pathophysiology of Heart Disease fifth Ed. Philadelphia: Lippincott Williams \& Wilkins; 2011,190-209.

2. Carapetis J R. Acute rheumatic fever. In : Fauci A S, Braunwald E, Kasper D L, Hauser S L, Longo D L, Jameson J L (Eds). Harrison's Principles of Internal Medicine 17th Ed. New York: McGraw-Hill; 2008, 2092-6.
3. Raju B S, Turi Z G. Rheumatic Fever. In: Bonow R O, Mann D L, Zipes D P, Libby P (Eds) Braunwald's Heart : A Textbook of Cardiovascular Medicine ninth Ed. Philadelphia: ElsevierSaunders; 2012, 1868-75.

4. Warnes C A. Pregnancy and heart disease. In: Bonow RO, Mann D L, Zipes D P, Libby P (Eds) Braunwald's Heart: A Textbook of Cardiovascular Medicine ninth Ed. Philadelphia: Elsevier Saunders; 2012, 1770-83

5. Webb J G. Percutaneous therapies for structural heart disease in adults. In: Bonow R O, Mann D L, Zipes D P, Libby P (Eds) Braunwald's Heart : A Textbook of Cardiovascular Medicine ninth Ed. Philadelphia: Elsevier Saunders; 2012, 1304-5.

6. Otto C M, Bonow R O. Valvular heart disease. In: Bonow R O, Mann D L, Zipes D P, Libby P (Eds) Braunwald's Heart : A Textbook of Cardiovascular Medicine ninth Ed. Philadelphia: Elsevier Saunders; 2012, 1468-539.

7. Leman S. Demam reumatik dan penyakit jantung reumatik. Dalam: Buku Ajar Ilmu Penyakit Dalam Edisi kelima Jilid II, Sudoyo A W, Setiyohadi B, Alwi I, Simadibrata M, SetiatiS (Ed). Jakarta: Interna Publishing; 2010:1662-70.

8. Cunningham F G, Hauth J C, Leveno K J.Abnormalitiesofthe placenta, umbilical cord, and membranes. In: Cunningham F G, Hauth J C, Leveno K J, Gilstrap L, Bloom S L, Wenstrom K D, Editor. Williams Obstetrics 22nd Ed. New york: McGraw-Hill; 2005, 355-6.

9. Wiknjosastro H, Saifuddin A B, Rachimhadhi T. Penyakit serta kelainan plasenta dan selaput janin. Dalam: Ilmu Kebidanan Edisi ketiga Cetakan kelima, Wiknjosastro H, Saifuddin A B, Rachimhadhi T (Editor). Jakarta: Yayasan Bina Pustaka Sarwono Prawirahardjo; 1999:357. 